\title{
THE EVOLUTION OF SEA-POWER UNDER THE FIRST TWO TUDORS ${ }^{1}$
}

In the story of Samson, as unfolded for us in the Book of Judges, we learn how of old a nation was not merely lifted from earth, but exalted to the stars by the efforts of one whom Nature had endowed with exceptional gifts; and the benefits conferred by him on Israel remained constant so long as Samson honoured with due observance the source from which his strength was derived. But first came moral perversity, then physical blindness, and the gifts of Nature became the badge of servitude and the seal of submission to triumphant enemies.

This allegory is generally given a literal translation. I prefer to interpret it this afternoon in a national sense and to apply it to ourselves.

England is dowered with a might and majesty of her own; but she does not derive them from the same source as the great empires of antiquity, or as the monarchies that have menaced the modern world. What Spain in the sixteenth century, what Germany in the nineteenth century endeavoured to achieve with tremendous armies, England has achieved without possessing such force. Indeed, the period of her greatest and most rapid expansion has synchronised with a period when her military stręngth has been reduced to a figure which it would be flattery to call exiguous. What, then, are the gifts with which England has been endowed by Nature, and by which the strength of this realm has been nurtured? I should like to attempt to do them justice; but time forbids anything but the merest summary.

In the first place, our country enjoys all the benefits of insularity, without the drawbacks of isolation. Geologists tell us that these islands are built upon the continental shelf; that time was when Kent and Picardy shared the same hill-range, and when the Thames was a modest tributary of the Rhine. Certain it is that to this day we are part and parcel of Europe ; and, if we are compelled to share the sorrows of its warfare, we at least profit by its contiguity in the arts of peace. Yet,

1 A Lecture delivered at King's College, London, Wednesday, Oct. 15, 1919. 
although we are part and parcel of Europe, we are mercifully separated from it by a ditch which Napoleon could not cross, a ditch that would present a similar abstacle even if a greater military genius than Napoleon was forthcoming. Secondly, England stands at the very hub, the very centre, the very navel of the land hemisphere. That means to say that all the great highroads of commerce lead directly to her doors. She occupies, with relation to the world's trade, the same position as the brain occupies in the nervous system or the heart in the circulation of the blood. Thirdly, her coasts are so fretted and indented with fiords, bays, gulfs, harbours, and river-mouths that in the whole tract of country-120,000 square miles-there is no place further than seventy miles from the sea. That means to say that from time immemorable all her shores have been thronged with seamen, and all her harbours with ships. Vessels that float and mariners to handle them are in England products as inevitable as sledges in North Russia or mountaineers in Switzerland.

These gifts constitute the heritage upon which the mighty fabric of our nation's grandeur has been erected. But if the fabric is to endure, if its glory is to be preserved, it is necessary that Government and People alike should take to heart the lesson of Samson and his shame. They must honour with due observance the source of their strength. They must steadily refuse to be blinded by the majesty of the edifice, and ever have in remembrance the foundations on which it rests. For what use to us are our water-frontiers without battleships to patrol them? What value attaches to a position where all the avenues of commerce converge, unless our merchandise covers the sea? And how is our fleet to be manned, and our merchandise to be carried, unless the ships and seamen that these islands breed are encouraged in the manner they deserve?

Unhappily, as a nation we have a suicidal habit of complacently contemplating our greatness, and overlooking altogether the causes from which it has sprung. Especially has this been the case at the conclusion of a great and world-wide war. Nothing would be easier than to multiply instances. But time presses; and I must content myself with one.

England had accepted the challenge of one of Europe's greatest war-lords. On the Flanders front the battle had swayed this way and that, but no decision had been reached. Talk of an immediate march upon Paris had, in fact, been put aside. To the whole world, which stood spectators, it appeared more and more manifest that the end of the struggle would be decided by 
a test of endurance. The last penny, it was said, would win. Still the armies on both sides faced each other unflinchingly. Still, from time to time, pacific propaganda were put forward, discussed, and put aside again. It was not until the last penny had been thrown into the balance, it was not until the last silver bullet had been moulded, that the belligerent Powers assembled under the same roof to affix their signatures to a treaty of peace. England in her island fastness emerged from the ordeal unseared by invasion, unscathed by rapine, loot, and murder. And was any credit given to the $\mathrm{Navy}$ for saving the State, for enabling the Government unmolested to improvise an implement with which to break in pieces the militarist rod? Not at all. The war produced three great admirals. One was lost with the best part of his squadron for want of a few precautions which ordinary foresight might have suggested; a second was pushed into retirement amidst universal applause because he had conducted a great fleet action in a rather different manner from that in which the man in the street would have conducted it; and a third, though he was offered an earldom and given the highest post of administration under the Board of Admiralty, did not receive that much higher compliment of having his campaigns studied in the way they deserved and with the close attention given to those of land generals of inferior merit. As for the people themselves, instead of being modest after what had happened, instead of reckoning life cheap and his own value small, every man thought himself entitled to get rich quick, and plunged into what can only be described as an orgy of profiteering. Even the Premier himself has by some been accused of thinking more of the profits than the law, and of substituting for the Ten Commandments a tariff of human souls.

Is it necessary for me to be more specific as to the period to which I refer? I refer, of course, to the opening years of the eighteenth century, to the last round of the struggle with Louis XIV., to the war of the Spanish Succession, and the Walpolean epoch of peace that followed it. The Navy was then reduced below the danger limit, and it is a cause for marvel that the greatness of England did not depart with that epoch's close. Happily, there were prophets in the land in those days, and two came forward to save their country. John Wesley, schooled in the wilderness of abstention and the desert places of self-denial, addressed his fifty thousand sermons to the erring human heart; and a minor prophet-perhaps the least of the minor prophetsJames Thomson, addressed one homily which went home, one 
sermon which it was the privilege of his own generation to understand and of succeeding generations to misquote:-

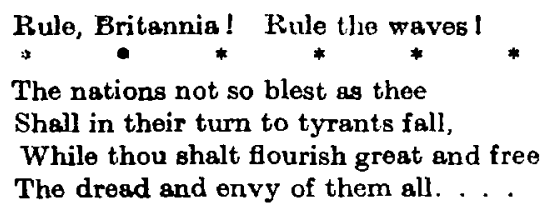

on one condition, and on one condition only,

Rule, Britannia! Rule the waves !

Lapses, such as that which occurred under Sir Robert Walpole, are so frequent in our history that, to be truthful, we must call them "periodic" rather than "occasional." And it is for this reason that we turn, as for an invigorating tonic, to the Tudor period; for then the rulers of this country consciously endeavoured to build upon the only foundation that can be trusted to sustain the weight of an island empire.

The founder of his line, King Henry VII., accomplished so much for our maritime welfare that it would be impossible in one afternoon to do full justice to his work. I shall therefore select four points haphazard from his general policy.

First of all, on coming to the throne, he endeavoured to improve the "Royal" Navy. That sounds a very simple remark; but its very simplicity has been a pitfall of deception. With his crown Henry VII. obtained the entire " Royal " Navy of his predecessor; and the "Royal" Navy of his predecessor amounted, in all, to four sea-going vessels. I have seen it stated somewhere that if Richard III. allowed his fleet to sink to a level of four ships, he deserved nothing less than to lose his crown. Such a comment almost staggers one by the ludicrous ignorance which lurks behind it. Four ships in a "Royal" Navy was a very average figure. Indeed, we may ask for what purpose a king required to number among his possessions a squadron of ships at all. Well, he wanted it primarily to carry him about from one place to another. The four ships that Henry VII. received with the crown corresponded with what to-day we call the Royal yachts. The word "yacht" was taken from our adversaries at the beginning of the Dutch wars in the seventeenth century. It was not known in the time of Henry VII.; otherwise, he might have called. his navy "The Royal Yachts." Four crown ships were found, as a rule, sufficient. But Henry from the first resolved to add to the number. He certainly went as far as twelve; some authorities 
say thirteen. What, then, was his reason for this augmentation? I do not answer the question immediately, because, in improving his private fleet, Henry, it is evident, paid much more attention to quality than to quantity. Indeed, it is arguable that the ships, which he acquired by purchase or other means, were not treasured for their own sake, but simply broken up to aid in new construction. There is even some reason for believing that during his reign Henry aimed at no more than replacing four vessels that were old and obsolete by four that were original and up to date. This much, at any rate, is evident : that the new vessels actually built by him numbered four; and it is to these four ships that we must direct our attention. They were all remarkable and noteworthy craft; but the biggest and best was the Regent.

It is always very difficult in untechnical language to describe ships, but the Regent must not be pushed aside without some attempt to appreciate her build. I will therefore compare her with a ship belonging to the navy of Warwick the Kingmaker. You will not at this point be surprised to hear that Warwick possessed a navy of his own. In fact, there was nothing to prevent anyone from having a navy except the expense of keeping it up. The largest navy in the country was the navy belonging to the City of London, though the navy of Bristol ran it very close from time to time. I speak of the Kingmaker's vessels in preference to those of the City of London, because we have beautifully drawn pictures of them, still happily surviving, and reliable ship pictures of that date are rare. When we look at one of the Kingmaker's ships we find a large vessel with a very large mast stepped amidsbips. In addition to this she had what can best be described as ambitious flagstaffs, one well forward, the other aft. These may have been used at times for a practical purpose. Upon them, that is to say, may have been set scraps of canvas to help the steering or handling of the ship. But their primary use was to spread abroad monstrous banners with all the vaunting arrogance of feudal blazonry. Of big sails the ship had only one.

When, however, we turn to Henry VII.'s Regent we find a very different ship. Instead of one mast she has four : foremast, main, mizzen, and bonaventure. And all these masts are big masts, carrying big sails. Not only that, but above the lower masts come topmasts also, and above the main topmast soars a top-gallant. It was obviously the design of Henry and his shipwrights to make their vessel as fast as possible; and so marked was

No. 19.--VoL. v. 
the advance they made over all that bad been done before, that it would be more natural to compare the Regent with Nelson's ships than with any afloat at the time when Henry won Bosworth Field. Here then we have an extraordinary plunge forward, and we shall see presently why it was made. But speed was not everything. It was no use making a speedy ship without giving her the means of taking care of herself, and therefore Henry armed the Regent with as many guns as she could take on board. How many guns the Kingmaker's ships mounted we do not know. Guns were first introduced into the Royal Navy about 1410. The Christopher of the Tower in that year mounted three; and it was probably a question whether these rudimentary weapons would not inflict more damage on those who laid them than on those at whom they were fired. In the next half-century, however, these little pieces of ordnance seem to have improved; and, though the whole question is wrapped in darkness, we may hazard the guess that Warwick's ships mounted thirty or forty of them. Fifty would, I think, be an outside estimate. But in the Regent there were no less than 225 : and such an armament, I need hardly add, in number exceeds that of any vessel that went before and of any vessel that has been constructed since. Henry's masterpiece, in short, was a tremendous ship, an epoch-making ship, a ship that demands comparison with the Dreadnought and Noah's Ark. And yet how vain it would be to look in the ordinary history-book for even so much as the mention of her name!

The Regent is memorable not only for her own sake, but memorable also for far-reaching changes which followed in her train. In the first place she caused a terrible upset and commotion in the royal dockyard. Note that in 1485 there was not more than one such centre. But one there was; for even four ships of old-fashioned build must have a base for their accommodation. Now the one royal dockyard that Henry VII. inherited takes us back to the time when the metropolis of England was not London, but Winchester. In those days Southampton Water formed a great avenue leading up to the King's capital city; and conveniently near to the port of embarkation the royal ships were berthed. The actual base was the River Hamble (famous for its strawberries), which empties into Southampton Water just opposite to the modern flying station at Calshot. Beside the Hamble, at Bursledon, stood the royal dockyard, if the word dockyard can be properly applied to what was merely a. collection of roomy sheds for housing the masts, and cables, 
and anchors, and ropes, and other gear. That was all that the King had; and to say truth, that was all that he needed.

The Regent, however, stubbornly refused to go over the bar of the Hamble. She could not be pushed over; she could not be pulled. They waited for high water, but to no avail. Even a spring tide would not carry her in. Henry was not the man to take undue risks. He decided, therefore, in the interests of the Regent that the royal dockyard must be shifted elsewhere, and he looked about for a suitable place. Eventually he selected an adjacent harbour called Portsmouth. The name takes one back a long way, and shows that the place had an identity of its own in times remote, like Falmouth, Dartmouth, and Teignmouth. Hitherto, however, it had enjoyed a merely local importance : henceforward, as headquarters of a yearly increasing Royal Navy, it began to assume that pre-eminence which it has kept almost ever since.

When Portsmouth was reached, and while the Regent lay at anchor, Henry inaugurated another reform, which, if anything, was more important than the shifting of his base from the mud-choked Hamble. It was the custom in those days when a ship wanted cleaning or repairing below the water-line to take all her heavy weights out of her and drag her at high tide up some river creek and dump her down on the mud. She was then kept in position by shoring poles, and a dock was built around her. The word "dock" means a hedge or stockade, a wall or barrier of upright poles plastered inside with mud, through which the last of the water percolated. In this primitive fashion big vessels were berthed, and during the winter months repairs were executed on their underwater timbers. But Henry refused to submit his Regent to treatment so undignified. She was too precious, too wonderful, too queenly altogether. $\mathrm{He}$ therefore invented an improved method, which has been employed by the world ever since. I mean the tidal basin or dry dock. It was an appropriately well-timed invention, and like the spinning-jenny, the water-frame, the mule, and the power-loom, attuned itself to the essentially practical genius of the Englishman. It would perhaps be too much to say that it emerged from the actual brain-case of the king himself : but in default of all evidence as to the name of a craftsman or engineer, the credit for the discovery must be given to the king.

And now leaving the Regent snugly berthed at Portsmouth, we may well ask ourselves why it was that Henry was so interested in the Royal Navy and so determined to improve it. 
His reason will strike us as strange until we remind ourselves that Henry lived in an age of transition, and straddled the boundary-line that divided mediæval from modern times. His four splendid ships, Regent, Sovereign, Sweepstake, and Mary Fortune, were not designed as royal yachts. Devout as he was in his love for all beautiful things, Henry was not the man to squander money on sumptuous sea-vehicles or luxurious travelcraft. He fitted his ships in the manner described, made them faster than anything else afloat, and better able to take care of themselves, solely in order that they might compete successfully for the blue ribbon of commerce. Do not run away with the idea that he was going to conduct great commercial enterprises himself. He was quite prepared to do so if time allowed. But his root scheme was more national and comprehensive. What he did was to hire out his ships. After her completion, there was bardly a year in which the Regent was not chartered by the merchants of Bristol or the merchants of smaller cities. Bristol was then the second city in the kingdom, but there were plenty of others that could afford the prices that Henry asked. Some secret adviser may have said to him, "If you hire out your ship, they will learn all her secrets"; and to such an insinuation there is no doubt that Henry would have replied, "I desire them to do so." The very reason why the Regent was let out on loan was that all who were interested might learn at first hand what the ideal merchantman might become. And no doubt, before the conclusion of the reign, all who could afford to do so were building Regents as fast as they could, instead of the smaller vessels that had satisfied them before they made the Regent's acquaintance.

I pass, by a rather violent transition, to another point in Henry's policy, which will probably strike you as even more paradoxical.

Supposing that war should break out! Henry VII., as all the world knows, would have done anything to prevent a recurrence of hostilities. But his throne, at least in the earlier part of his reign, was none too secure, and foreign Powers might be tempted to interfere. What then? To be armed point-device in the day of battle, Henry did all he could to encourage the Mercantile Marine. Obviously, with a Royal Navy of four sail, he could not go to war with his own ships; and, that being the case, all his hopes were based upon the fleets of England as a whole. From time immemorial the Crown had exercised the right to requisition all the merchantmen of the realm. Push 
your researches back as far as you can, you will find this true, wherever there is evidence available: and in your own day you have seen the old procedure justified by its revival in the war now happily at an end.

In the Middle Age, you see, there was no English naval warfare in the modern sense, no deliberate attempt of one organised fleet to defeat another organised fleet by burning, sinking, or destroying the units of which it was composed. There was a great deal of cross-Channel campaigning, which meant to say that soldiers were put into transports and taken from France to England, or from England to France-the kind of campaigning which in the recent war found some exemplification in the work of the Dover Patrol. There were exciting moments from time to time: but as a rule there was an incessant round of dull, monotonous work which roused no interest in the general public. An endless succession of transports went backwards and forwards : and for transports no better reliance could be placed than on the vessels of the Mercantile Marine. The king, as already stated, based his hopes on them; in time of war he put his whole dependence on them. This is well illustrated by the conduct of Edward III., who, though generally regarded as a veritable organiser of victory, was in reality no better than a traitor to the vital (that is to say, the maritime) interests of his realm. Edward III. presumed upon the royal prerogative. No sooner was a good ship built than be requisitioned her for his endless wars, and in so doing he sapped the strength of the Mercantile Marine and drained the country of its life blood. Had he reigned much longer, the damage done might have been for centuries irreparable; for the sbipowners, sooner than build big ships for the Crown to requisition, stopped building altogether: and the merchant shipping of this country declined more quickly and more dangerously than it has ever done before or since.

Henry adopted exactly the reverse process. He desired to encourage the Mercantile Marine, and out of his fertile brain he devised exactly the right kind of stimulus. He evolved what we may call in the language of our own day a Standard ship: and he then offered a bonus or money reward for all vessels that exceeded his model in size. The matter perhaps deserves to be put into more concrete terms : and Henry's own figures may at this point be adduced, if we preface them with the remark that our own values and measurements differ too widely from his to make the statistics etymologically instructive. 
He found by calculation that the ressel best suited to his needs for the transportation of troops was a vessel of something rather more than a burthen of one hundred tons. He therefore offered a money reward of five shillings per ton for every ton of a new merchantman's measurement over and above one hundred tons. If we knew the exact connotation of the Tudor word "ton" and the modern value of the Tudor "shilling," these sordid details might speak to us more eloquently. But it will not perhaps be very far wrong to say that Henry encouraged the building of big merchant ships by offering about five pounds sterling of modern money for every unit of cubic capacity after one hundred units had been exceeded. That leaves us free to examine the word "ton," as Henry employed it, in connection with a third page of his maritime programme.

It will surprise you to learn, if you have not already acquired the fact for yourselves, that, though there were at Henry's accession innumerable English merchantmen, these ships were not concerned or engaged in the import or export trade. There were good markets for English-made goods abroad: and England, then as now, was largely dependent on materials which she could not herself produce. But the carriage of these commodities was not controlled by English merchants or English shippers. The vessels which this country constructed for purposes other than the fisheries were occupied primarily with the coastwise traffic. This was very considerable, for roads were few and exceedingly bad ; and the risks of land transport were not confined to robbery and pillage. Still, the volume of coastwise traffic hardly made amends for the absence of ocean commerce or for the fact that the import and export trade were almost exclusively in the hands of foreigners. To this sad state of things there was only one exception worthy of record. English-built vessels managed to compete to some extent in the carriage of wine from southwest France. Guienne had once been an English province, and ships from this country that cared to visit Bordeaux were still welcomed as old friends.

Setting to work on this slender foundation, Henry began to build a protective wall for what he deemed should be England's foremost industry. By the first and earliest " Navigation Act" he forbade the introduction into England of a single barrel of Bordeaux wine in any but an English bottom. And it is from this direction that light is thrown on the Tudor method of measuring ships. A barrel of Bordeaux wine was called a "ton," and along the first all-English ocean trade route ships 
came to be described as capable of carrying so many barrels of Bordeaux wine. A vessel's capacity, in short, was henceforth known as "tonnage." The name has survived until to-day, though it no longer means what it meant four centuries ago. We must be careful, therefore, not to institute rash or ill-judged comparisons. When we learn that Henry's standard ship was able to stow in some unspecified part of her hull an easily ascertainable cargo from Guienne, we earn, thereby, no excuse for supposing that our Queen Elizabeth would accommodate, among other things, 27,500 barrels of Bordeaux wine. And equally ridiculous would it be to conclude that one of our Transatlantic liners to-day is five hundred times as large as the Regent. The figures, in short, that survive from Henry's reign do not belp us now to form a right conception of the bulk or scale of his ships.

I now come to the last item that I have selected from Henry's maritime policy. It is the biggest and most important of the series; but, to appreciate it at its proper value, we need to bring our imagination very strongly into play.

When the first of the Tudors won his crown on the battlefield of Bosworth, England was regarded as the outermost fringe of the mysterious West, an island half hidden in Cimmerian gloom, the Ultima Thule. Beyond her furthest rim of cliffs, steep chasms, and sobbing crags, there was supposed to roll the boundless, illimitable ocean-river that circled all the earth. Seven years after Bosworth, as everybody knows, Columbus flung himself into the infinity of this dimensionless gulf, proved to an incredulous world that it could really be crossed, and in doing so opened the gate into a region which men recognised as Marco Polo's Cathay, and which for thirty years to come they implicitly believed to be Australasia.

When the earlier Columbian voyages provided little beyond a demand for further pioneers, the first kinetic impulse of the Castilian Government spent itself. But Henry of England with both hands welcomed the invitation held out by Transatlantic possibilities. For the very backbone of his whole policy was to turn his face to the sea and his back on the cockpit of Europe : and nowhere could he find better scope for his ambition than in pointing and guiding the people he ruled to wider horizons in the West.

In the year 1497 the first English expedition of discovery set out under John Cabot. The results were encouraging, and a second expedition in the following year was entrusted to the same navigator. Sebastian Cabot followed John : and from the 
hour of the first venture to the hour of Henry's death we can trace the evidence of a never-ceasing series of English voyages. The only reason-we speak it with shame-why we know less of later voyages than the earlier ones was that they were conducted by Englishmen instead of by Venetians. The more closely the subject is pursued, the more diligently research is pushed home, the more numerous are the English expeditions which are found to have been conducted under the patient encouragement of Henry VII. No land of pearl and gold was found, such as corrupted the Spaniards and beguiled the Portuguese. Even Henry, it is obvious, grew rather down-hearted when India persistently refused to declare itself. And yet how transcendent was the gain to this country! In wrestling with the task of navigating the Atlantic his vessels received new strength, and in the storms of that ocean his seamen were tried.

With these brief and inadequate remarks I must take leave of Henry VII., making bold to remind you, ere we bid him adieu, that this is the man who, with his nervously twitching hands and furtive glance, struggles somewhat apologetically into the history-books wearing about his neck the millstone of dulness fastened there by Bishop Stubbs.

If I were to sum up the work of Henry VII. in a single word, I should say that he was his own "Admiral." But that will not convey very much to those who recognise the word in its modern meaning only. The medirval Admiral, or "Lord High Admiral" (as in Stuart times he came to be called), was one of the great officers of State. We find mention of him by name as early as the reign of Edward I.; and it is probable that he existed much earlier, even though no record of his personality has yet been found. To put the matter in another way, we may confidently assert that, as early as the reign of Edward I., the King of England had already handed his trident to a deputy, and in so doing decentralised his marine administration.

The offices of the Admiral were twofold. He was, as it were, a "First Lord," without, of course, the modern Minister's responsibility to a popularly elected House of Parliament; and he was also a functionary resembling tio Master of the Rolls. It was his main duty to do right and justice to the most turbulent of the king's lieges, that is to say, the seafaring population; and his perquisites as a great judge made him one of the wealthiest individuals in the realm. It was also his duty, when occasion called, to prepare a sea-borne expedition, or to put the country in a posture of defence against the fleets of a would-be invader. 
The most familiar figure in the roll of Admirals is Charles, Lord Howard of Effingham, first Earl of Nottingham of the Howard creation. And I rather suspect that he is remembered in chief for the very thing which makes him an exception among the holders of his office. For, as all the world knows-he went to sea! An ingenious pleader might make out a good case for putting the Board of Admiralty afloat. Or, again, it might be urged that the days of Howard of Effingham are with us again, now that wireless telegraphy can put "my lords" in hourly touch with a Commander-in-Chief's quarter-deck. But all that does not alter the fact that Howard of Effingham, when he went in person to fight the Armada, was leaving his own province. The Admiral's duties, when they were not juridical, were purely administrative; and it is as an administrator of the Lord Admiral type that King Henry VII. makes to-day his strongest claim on our regard.

The point is worth insisting upon, because Henry, by creating a new rôle for the Lord Admiral and stimulating the Lord Admiral's department, had endowed his own pet schemes with a certain measure of permanence. The Admiral, of course, had nothing to do with the Royal Navy; nothing whatsoever. But under the second of the Tudor kings he still extended Henry VII.'s bonus to merchant shipping; he still carried out the Navigation Act, confining the import of Bordeaux wine to English bottoms; and he still granted licences to shipowners to send ships across the Atlantic. In this last branch of his activity we may trace, perhaps, a reflex action of the maritime world upon the Viceroy who ruled it. For the Admiral himself could not, independently of the Crown, inaugurate fresh voyages of discovery; and those who asked his permission to make a passage to the West were those who desired a quick and definite return on their outlay, men who had already filled their barques with cod off the banks of Newfoundland. It was the commercial value of the fish rather than the initiative of the Lord Admiral that caused the Transatlantic voyages to continue.

It was well, however, that the Admiral was there to answer the call of his seafaring subjects; for the sceptre of England unhappily fell from the enlightened hands of Henry VII. into the reactionary hands of Wolsey. The pendulum was set swinging in the opposite direction; and the quest of the Indies ended abruptly. England once more plunged into the vortex of continental politics, and forgot the newer destiny that awaited her beyond the ocean paths. Indeed, it is not too much to say 
that the work of Henry VII. and the admirals who inherited his teaching might have come to an eventual full stop, if behind the insatiable egotiom of Wolsey there had not lurked the bulky fgure of Meus Rex.

Henry VIII., like many thousands of Englishmen since, was brought up by his father to adore ships. Nothing pleased him better than to dress as a boatswain, substituting for the ordinary material cloth-of-gold and velvet, but hanging round his neck a boatswain's whistle, and (to quote a Londoner who from the Royal mouth probably heard the strident music of the pipe for the first time) "blowing upon it as lustily as upon a trumpet."

As heir of the ages Henry wasted on H.M.S. Regent about as much admiration as a modern aspirant to a Rolls-Royce would devote to a well-preserved velocipede. The Regent was well enough in her way, a source of amazement when she was built, but to those who kept abreast of the times-incontestably obsolescent. Henry from the very hour of his accession desired to replace her by something more remarkable; and the progress of invention threw an unexampled chance in his way.

In 1509 the development of heavy ordnance had reached a point beyond which it was not destined to advance until the engineering renaissance of the nineteenth century. The guns that were being cast in the Low Countries, especially in the town of Mechlin, were as good as anything England possessed when she fought against Russia in the Crimean War. Now there was in heavy artillery something that appealed irresistibly to Henry VIII.; something demoniacally destructive that proclaimed the two akin. The Hammer of the Monks asked for no better sport than to watch great gunnery experiments. In the region of Houndsditch he would have enormous targets erected, and crow with delight when he saw them demolished by the discharge of his monstrous weapons. We must think of him, then, on his ordnance-ground being struck one day by a happy thought. What a splendid thing to put some of these ghastly engines of destruction inside the royal ships! What a power which no other ship would bave, if some of these tremendous pieces of artillery were mounted inside his own! The shipwrights were called to his council; and one and all, when they heard the king's project, advanced emphatic protests. The scheme, whatever its merits might be, was manifestly impracticable.

If you will call to mind any picture of a mediæval ship that you have seen, you will easily understand the shipwrights' con- 
tention. You will remember that the mediæval ship had at either end a rather curious edifice with battlemented tops, a forecastle in the bows, an aftcastle in the stern. These edifices did not share the strength of the hull, above which they were raised. The name " castle," if not actually given in derision, was probably bestowed out of compliment to their wooden battlements. The towers themselves were made of so many scaffolding-poles and so much planking, the erection being not unlike the cagework that supports the masons and builders of to-day. But though unsubstantial compared with a vessel's hull, the " castles" were powerful enough to sustain the weight of any mediæval weapon, even the multitudinous pieces of artillery, with which Henry VII. loaded the Regent. The Regent's guns, however, did not belong to the category of heavy ordnance. And heavy ordnance, so the shipwrights argued, could not by any possibility be mounted in such a ship as the Regent, for the simple reason that the discharge of a single piece would effectually flatten the castle which contained it.

Henry VIIT. was not the least impressed by this consensus of expert opinion. He made short work of his shipwrights, threatening them with the direst penalties if they raised any further objections. Was it likely that he, when he had once made up his royal mind, would change it because there were difficulties with which to contend? He had called them together not to assist him to a decision, but to remove the difficulties which blocked the path of progress.

The problem confronting the agitated constructors was finally solved by one who well deserves to be had in remembrance by his countrymen-James Baker, Master Shipwright to the King. He received, it is true, no outward token of the royal gratitude; but it is clear that he established a solid claim to recognition: for, though be was found to be tainted by the Lutheran heresy, his sin was actually overlooked and his misdemeanour condoned. Baker saw from the first that the big guns would have to be mounted in a vessel's hull; and that the embrasures through which they were pointed would have to be closed (when required) in order to keep out the water. Anyone could cut a hole in a ship : the task was to block the aperture when opened. Baker adapted for his purpose a French invention, which some have credited to Descharges of Brest. This was a patent door, called by its inventor a porte, which could be fastened securely inside the ship, and could be trusted to withstand the inrush of the sea. The door was of purely mercantile origin, and had been found 
useful hitherto for lading and unlading cargo. It may possibly have been in use for years before Descharges improved it; and, if (as seems probable) it was always cut on the larboard quarter, may supply an explanation of the enigmatical appellation for the left side of a ship.

James Baker boldly annexed the "Port"; but, instead of contenting himself with a single specimen, cut as many doors as he dared for gunembrasures in the very bellies of the King's ships. No doubt he improved the mechanism of these patent shutters : for they had to be opened and closed, not once per voyage like the cargo-hole of a merchantman, but again and again whenever the guns were laid. Details are lacking : but we know enough to say that with the evolution of the Broadside ship, that is, of a vessel mounting inside her hull as many big guns as she could conveniently carry, Henry VIII. revolutionised the science of shipbuilding and endowed his realm with a weapon of war which was to win all battles at sea for three hundred years to come, a weapon of war compared with which the Zeppelin is but as dust in the balance, and the Tank but a very little thing. For it must not be thought that Henry's guns were in any sense inferior to those used at Trafalgar. The heaviest weapons that Nelson possessed threw a solid iron shot weighing thirtytwo pounds. Henry's guns threw heavy iron balls of fifty, ninety, and two hundred and sixty pounds' weight. The tendency in subsequent years was to reduce the size of the pieces used, in order to admit of greater ease of handling and greater rapidity of fire-drill.

There is a popular impression that Henry christened his earliest broadside man-of-war Great Harry or Henri Grace à Dieu. But this is a mistake. He constructed at least two other ships to carry heavy ordnance-the Peter Pomegranate and Mary Rose -before the Great Harry was built. For some reason, however, not now easy to determine, the Great Harry seized the imagination of the people of that day, and has held a place in men's memories ever since. Not that the name for its own sake matters very much. The point to remember is that, in the security that such sea-mammoths afforded, Henry could not only break the bonds of Rome, not only hack in pieces the fabric of mediæval monasticism, but do so with complete impunity.

You may think that, in the development of England's maritime power, Henry was unlikely to achieve anything of greater magnitude. But $I$ will name immediately another change that caused even greater consternation in the breast of the Venetian 
Ambassador, who at this time was warning the Doge and Council of Ten that their naval supremacy was likely to be challenged. Not content with one or two "super-Regents" or even with a round dozen, Henry went on multiplying the crown navy until the total figure numbered eighty-five. That was an aggregation of naval strength in the hands of a single monarch that put anything similar that had ever been heard of into a remote and hazy background. Henry VIII. possessed among his personal belongings a floating force infinitely greater and stronger than any nation on earth could bring against him. You may have wondered why it is that Britons flatter their fleet with a regal prefix which they deny to their army. Henry VIII.'s naval administration supplies the answer : for bis privately-owned force was competent (without the customary requisition) to fulfil all national needs.

These twin revolutions-the production and the multiplication of the heavily-armed ship-brought other important changes in their wake. In the first place they broke down the dockyard system altogether. Portsmouth was insufficient. Three new dockyards were added. Woolwich and Deptford were chosen, so that the King, living at his beautiful Palace at Greenwich, might have one on either side of him. He was never happier than when looking out of the Palace windows and gazing at the brave pageantry that the river afforded. He planned also the great dockyard at Chatham, though it was not completed when he died. But infinitely more important than the breakdown of the dockyard system was the breakdown of the administration. In mediæval days the King's Navy was cared for by a custodian called the "Clerk of the King's Ships." We find mention of this worthy as early as the reign of King John, but he probably had an existence long before he is specifically named. His headquarters in mediæval days were at Bursledon on the Hamble; and, when Henry VII. abandoned that place, he shifted his quarters to Portsmouth. But what could the wretched man do with eighty-five "super-Regents"? He could not possibly manage all the work they entailed. Nor could he very well be expected to live in four places at once. Yet Portsmouth, Woolwich, Deptford and Chatham, all alike demanded a resident Commissioner. At first Henry appointed four "Clerks of the Ships"; but the experiment was costly and gave no satisfaction. Then at the last, quite late in his reign, he evolved (apparently from his inner consciousness) a committee known as the "Navy Board." This body adopted the principle of the division of labour, and numbered 
among its mambers the Treasurer of the Navy, the Surveyor, the Controller, the Master of the Ordnance, and the Clerk of the Ships. The Board was unlike anything that had as yet been created in Western Europe, and came at least a century before its time. It was ready at a moment's notice not only to equip and send to sea the King's fleet of eighty-five fighting-ships, but to prepare and arm more than double that number supplied by the Mercantile Marine. Such being the state of his maritime defence, you can imagine the contemptuous indifference with which Henry VIII. snapped his fingers at the whole world.

It was not given to him, any more than to his father, to see his maritime work tested by the stern reality of war. And that, perhaps, is why such far-reaching reforms have been so generally overlooked. Drake, as the champion of England against Spain, has rightly been given the premier place in the naval story of the sixteenth century. And yet Drake would have been helpless if be had not found ready to his hand the weapon forged by the Early Tudors.

The mention of Drake brings our argument back to the point from which it started: for the glory of the Elizabethan age vanished as soon as the great queen's sceptre descended to the monarch who made privateering illegal, who slew the surviving apostle of sea-power, and discovered in the mirror of his selfconceit the image of Heaven's deputy.

And here lies the moral for those who will read it. Once more, as in 1603 and 1714 , we stand at the parting of the ways. Our country has been saved from nameless horrors by its unshaken hold on searsupremacy. And already the remembrance of the horrors is fading and with it the knowledge of the things that belong to our peace. Whither, then, are we to steer the ship of state? Shall we drift with closed eyes, like James I. and Walpole, towards the quicksands of naval neglect? Or shall we safeguard our children and our children's children by a maritime policy not unworthy of those who launched the Regent and the Henri Grace à Dieu?

Geoffrey Callender. 